\title{
The Fluorescent Pigment of Pseudomonas fluorescens: Biosynthesis, Purification and Physicochemical Properties
}

\author{
By J. M. MEYER \\ Laboratoire de Biochimie Microbienne, 4 rue Blaise Pascal, \\ Université Louis Pasteur, 67070 Strasbourg Cedex, France \\ AND M. A. ABDALLAH \\ Laboratoire no. 31 associé au CNRS, Institut de Chimie, 1 rue Blaise Pascal, \\ Université Louis Pasteur, 67008 Strasbourg Cedex, France
}

(Received 7 February 1978; revised 4 April 1978)

\begin{abstract}
The biosynthesis of a yellow-green, fluorescent, water-soluble pigment by Pseudomonas fluorescens occurred only when the bacteria were iron-deficient and was not directly influenced by the nature of the organic carbon source. The pigment formed a very stable $\mathrm{Fe}^{3+}$ complex and was purified in this form. Pseudomonas fluorescens produced only one molecular species of fluorescent pigment; however, its lability under mild alkaline conditions led to the formation of several pigmented decomposition products. The spectral properties of the pure pigment, its molecular weight $(1500 \pm 75)$ and its stability constant for $\mathrm{Fe}^{3+}$ (of the order of $10^{32}$ ) were determined. Both its biosynthesis and its chemical properties (formation of a stable $\mathrm{Fe}^{3+}$ complex) suggest that the fluorescent pigment is a desferrisiderophore.
\end{abstract}

\section{INTRODUCTION}

The synthesis under certain growth conditions of yellow-green, fluorescent, water-soluble pigments is a characteristic property of some Pseudomonas spp. (Stanier et al., 1966). These species are all members of the same intra-generic genetic homology group (Palleroni et al., 1973). They include $P$. aeruginosa, $P$. putida, $P$. fluorescens and phytopathogens of the $P$. syringae type (Palleroni \& Doudoroff, 1974).

Many different environmental factors affect the synthesis of these pigments, notably the chemical nature of the organic carbon and energy source (Lepierre, 1895; Sullivan, 1905; Blanchetière, 1920; Giral, 1936; Gouda \& Greppin, 1965; Gouda \& Chodat, 1963), the degree of aeration of the culture medium (Elliot, 1958; Lenhoff, 1963), pH and light (Greppin \& Gouda, 1965) and the cations $\mathrm{Mg}^{2+}$ (Georgia \& Poe, 1931), $\mathrm{Zn}^{2+}$ (Baghdiantz, 1952; Chakrabarty \& Roy, 1964a) and $\mathrm{Fe}^{3+}$ (King et al., 1948; Totter \& Moseley, 1953; Lenhoff, 1963; Palumbo, 1972; Lluch et al., 1973). No clear-cut physiological role has so far been assigned to this class of pigments. Various structures have been proposed for the pigments including pteridines (Giral, 1936; Chakrabarty \& Roy, 1964b), flavines (Birkhoffer \& Birkhoffer, 1948) and pyrroles (Lenhoff, 1963; Greppin \& Gouda, 1965), but none is supported by unequivocal chemical evidence.

The observation that the fluorescent pigment synthesized by a strain of $P$. fluorescens can form a stable complex with $\mathrm{Fe}^{3+}$ has led us to re-examine the conditions that govern its formation, its chemical structure and its physiological role. We describe here the factors that affect pigment synthesis, the purification of the pigment and its physicochemical properties.

Terminology. Turfreijer (1942) proposed the term 'pyoverdine' for the yellow-green, 
fluorescent, water-soluble pigment of $P$. fluorescens: he chose this name by analogy with that of the phenazine pigment, pyocyanine, produced by $P$. aeruginosa. This designation is preferable to those of 'bacterial fluorescein' or 'fluorescin' which have also sometimes been used in the literature (King et al., 1948; Lenhoff, 1963). Other authors (Elliot, 1958; Hulcher, 1968) have extended the name of pyoverdine to include all pigments produced by fluorescent pseudomonads. However, since preliminary unpublished studies have shown that there are minor structural differences between the pigments of the different species of fluorescent pseudomonads, it seems desirable to designate the pigments of this class by a suffix indicating the species responsible for their production, e.g. pyoverdine $\mathbf{P}_{\mathbf{P t}}$ for the pyoverdine produced by $P$. fluorescens.

\section{METHODS}

Organism. The strain of P. fluorescens employed was isolated by Wurtz (1954) and is held in the Czechoslovak Collection of Microorganisms as CCM 2799. In terms of the taxonomic criteria proposed by Stanier et al. (1966), it is $P$. fluorescens biotype B.

Media and growth conditions. The standard succinate medium used for most experiments contained ( $\mathrm{g}^{-1}$ in distilled water): $\mathrm{K}_{2} \mathrm{HPO}_{4}, 6 \cdot 0 ; \mathrm{KH}_{2} \mathrm{PO}_{4}, 3 \cdot 0 ;\left(\mathrm{NH}_{4}\right)_{2} \mathrm{SO}_{4}, 1 \cdot 0 ; \mathrm{MgSO}_{4} .7 \mathrm{H}_{2} \mathrm{O}, 0 \cdot 2$; succinic acid, 4.0. The $\mathrm{pH}$ was adjusted to $7 \cdot 0$ by addition of $\mathrm{NaOH}$ prior to sterilization. For some experiments, citric acid $\left(4.0 \mathrm{~g} \mathrm{l}^{-1}\right)$ was used in place of succinic acid.

The standard medium described above contains no added source of iron. In some experiments, it was supplemented with $\mathrm{FeCl}_{3}\left(1 \mathrm{mg} \mathrm{Fe} e^{3+} 1^{-1}\right.$, unless otherwise stated). In other experiments, traces of iron were removed from the standard medium by complexing with 8-hydroxyquinoline (Waring \& Werkman, 1942) or by bathophenanthroline (Theodore \& Schade, 1965), followed by chloroform extraction of the iron complex.

Cultures were grown at $25^{\circ} \mathrm{C}$ in 1 litre Erlenmeyer flasks containing $500 \mathrm{ml}$ medium and subject to mechanical agitation.

Measurement of growth and pigment synthesis. Bacterial growth was estimated turbidimetrically at $600 \mathrm{~nm}$; from these measurements cell dry weights were determined using an appropriate calibration curve. To determine the concentration of fluorescent pigment in culture media, bacteria were removed by centrifugation and the absorbance of the supernatant liquid was measured at $400 \mathrm{~nm}$; measurements were converted to a weight basis using the known absorption coefficient.

Isolation and purification of the fuorescent pigment. Bacteria were grown for $40 \mathrm{~h}$ at $25^{\circ} \mathrm{C}$ in standard succinate medium, the $\mathrm{pH}$ being maintained in the range of 7.0 to 7.3 by periodic addition of $\mathrm{HCl}$. At the time of harvesting, batches were pooled to a volume of $201 ; \mathrm{FeCl}_{3}\left(200 \mathrm{mg} \mathrm{Fe}^{3+} \mathrm{l}^{-1}\right)$ was then added to the culture, which was centrifuged, the pelleted cells being discarded. The supernatant was concentrated to approximately 1 litre under reduced pressure, saturated with $\mathrm{NaCl}$, and extracted with 0.5 vol. $\mathrm{CHCl}_{3} / \mathrm{phenol}$ $(1: 1, \mathrm{v} / \mathrm{w})$. The aqueous phase was discarded, and the organic phase was treated with 2 vol. diethylether and $100 \mathrm{ml}$ distilled water. The aqueous phase, containing the pigment-iron complex, was re-extracted three times with ether in order to remove phenol completely, and then evaporated under reduced pressure. This solution $(20 \mathrm{ml})$ was applied to a column of CM-Sephadex C25 $(2.5 \times 90 \mathrm{~cm})$ eluted with $0.1 \mathrm{M}-$ pyridine/acetic acid buffer (pH 6.5). A front-running minor fraction, generally representing less than $10 \%$ of the total, was shown by electrophoresis to contain a mixture of pigmented degradation products. The major fraction consisted of the native Fe(III)-pigment complex. Repetition of the CM-Sephadex C25 step showed this fraction to be $99 \%$ pure, in agreement with the results of electrophoretic analysis. The yield (after lyophilization) was about $130 \mathrm{mg}$ per litre of the initial culture medium.

Preparation of the iron-free pigment. The Fe(III)-pigment complex $(500 \mathrm{mg})$ was suspended in $50 \mathrm{ml}$ distilled water, and the $\mathrm{pH}$ was adjusted to 4.0 with $10 \%(\mathrm{v} / \mathrm{v})$ aqueous acetic acid. A solution $(5 \%, \mathrm{w} / \mathrm{v})$ of 8-hydroxyquinoline in chloroform $(150 \mathrm{ml})$ was added, and the mixture was stirred vigorously in a stoppered flask. The $\mathrm{pH}$ of the aqueous phase was re-adjusted to $4 \cdot 0$, and this phase was re-extracted four times with $150 \mathrm{ml}$ of 8-hydroxyquinoline/chloroform solution. The aqueous phase was washed with chloroform to remove 8-hydroxyquinoline, concentrated to $20 \mathrm{ml}$ and applied to a column of Sephadex G25 $(2.5 \times 90 \mathrm{~cm})$, from which it was eluted with distilled water as a single peak. The yield was $450 \mathrm{mg}$ of pure iron-free pigment. This treatment was performed as rapidly as possible to minimize decomposition of the pigment.

Electrophoretic analysis. Electrophoresis of the pigment $(300 \mathrm{~V}, 30 \mathrm{~min})$ was done in cellulose acetate sheets using two buffer systems: 0.1 M-pyridine/acetic acid (pH 5) and sodium veronal ( $\mathrm{pH} \mathrm{10).} \mathrm{Spots} \mathrm{were}$ visualized with ultraviolet light from a lamp having a major emission at $350 \mathrm{~nm}$.

Tonometry. Measurements were made with a vapour pressure osmometer model 302 (Mechrolab, Moun- 

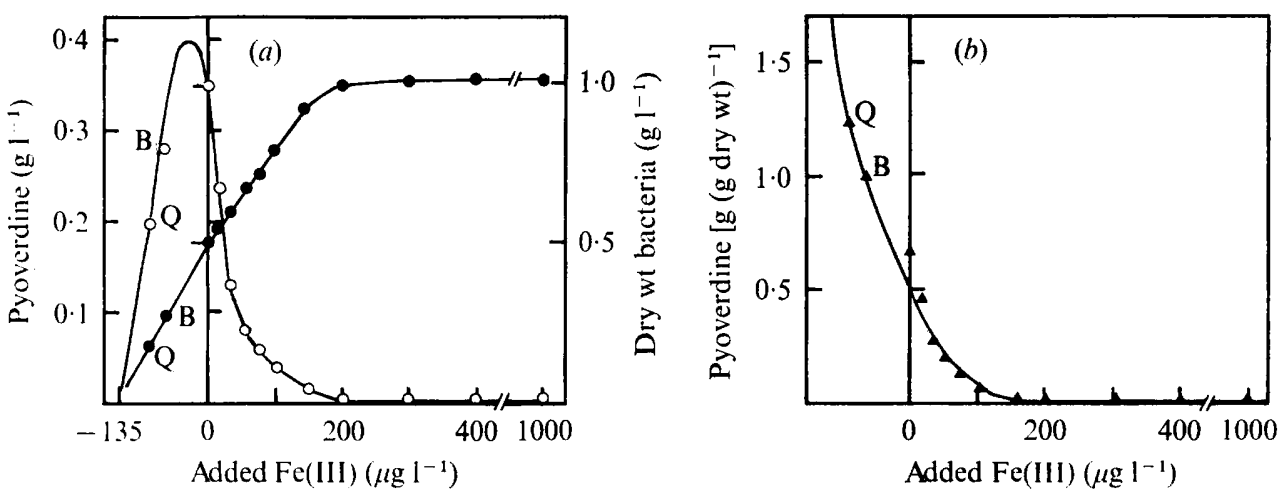

Fig. 1. Growth and pigmentation of $P$. fluorescens as a function of $\mathrm{Fe}(\mathrm{III})$ present in the succinate medium. (a) Growth ( () and pigmentation $(O)$ were determined as described in Methods. Points $B$ and $Q$ correspond to the standard media pretreated with bathophenanthroline (B) or 8-hydroxyquinoline (Q) (see Methods). Negative values on the abscissa correspond to the amount of Fe(III) present in the media as a contaminant. (b) Amounts of pyoverdine $\mathrm{PP}_{\mathrm{P}}(\mathrm{g}$ ) synthesized from $1 \mathrm{~g}$ dry wt bacteria (derived from Fig. 1a).

tain View, California, U.S.A.), using a Hewlett-Packard probe for aqueous solutions at $37^{\circ} \mathrm{C}$, with streptomycin sulphate as a standard. Aqueous solutions containing 15 to $60 \mathrm{mg}$ pigment $\mathrm{ml}^{-1}$ were examined.

Spectra. Absorption spectra in the visible and ultraviolet regions were determined with a Leres Spila 50 or a Cary 118 (Varian) spectrophotometer. Fluorescence spectra were determined with a Zeiss ZFM4C instrument.

Stoicheiometry of the $\mathrm{Fe}(I I I)$-pigment complex. A cuvette $(1 \mathrm{~cm}$ light path) was supplied with $0 \cdot 15 \mathrm{ml}$ of an aqueous solution $(0.65 \mathrm{~mm})$ of the iron-free pigment and $2.85 \mathrm{ml}$ of $0.1 \mathrm{M}$-acetate buffer ( $\mathrm{pH} 5 \cdot 2)$. Successive additions $(5 \mu \mathrm{l})$ of a freshly prepared aqueous solution $\left(3.25 \mathrm{~mm}\right.$ ) of $\mathrm{FeCl}_{3}$ were then made, and the absorption spectrum of the mixture was measured after each addition.

Determination of the apparent stability constant of the Fe(III)-pigment complex. Solutions containing $50 \mu \mathrm{M}$ Fe(III)-pigment complex and $15 \mathrm{mM}$-EDTA were prepared in a series of buffers $(0 \cdot 1 \mathrm{M})$ : acetate buffer (pH 5.4), phosphate buffer (pH 6.0 to 8.0) and glycine/ $\mathrm{NaOH}$ buffer (pH 10.0). Known amounts of the solutions of EDTA and Fe(III)-pigment complex in each buffer were added to a $50 \mu \mathrm{M}$ solution of the Fe(III)pigment complex dissolved in similar buffer, the total volume of the system being maintained constant at $6.0 \mathrm{ml}$. Under these conditions, the initial concentration of the Fe(III)-pigment complex was constant. Absorbances at $450 \mathrm{~nm}$ were determined after they had reached constant values.

Radioactivity. Radioactivity of ${ }^{59} \mathrm{Fe}$ was measured with a Gammamatic instrument (SAIP-CGR, 75015 Paris, France).

Chemicals. Succinic acid and citric acid (analytical reagent grade) were purchased from Merck, and ${ }^{59} \mathrm{Fe}$ (as ferric citrate) from CEA ( 91190 Gif-sur-Yvette, France).

\section{RESULTS}

Influence of $\mathrm{Fe}^{3+}$ concentration on growth and production of pyoverdine $\mathrm{p}_{\mathrm{p}}$

Growth of $P$. fluorescens in standard succinate medium (which contained no added iron) was accompanied by excretion of pyoverdine; excretion ceased as the culture entered the stationary phase. Addition of $1 \mathrm{mg} \mathrm{Fe}^{3+} 1^{-1}$ to the culture medium almost doubled the growth yield but completely repressed formation of pyoverdine. When $\mathrm{Fe}^{3+}$ was growthlimiting $\left(<200 \mu \mathrm{g} \mathrm{Fe}^{3+} 1^{-1}\right)$, there was an inverse relationship between the iron content of the medium and the amount of pigment synthesized after entry into the stationary phase (Fig. 1).

Pretreatment of the standard succinate medium to reduce its content of contaminating iron (see Methods) diminished the growth yield, while significantly increasing the amount of pigment produced (points B and Q in Fig. 1a). The amount of pigment synthesized per unit of cell mass was inversely related to the initial $\mathrm{Fe}^{3+}$ concentration of the medium under 
Table 1. Growth and pigmentation of P. fluorescens cultures in iron-deficient or iron-sufficient citrate media

The measurements were made after the cultures had entered the stationary phase. Iron-supplemented citrate medium was standard citrate medium supplemented with $1 \mathrm{mg} \mathrm{Fe} \mathrm{F}^{3+} \mathrm{1}^{-1}$ (added as $\mathrm{FeCl}_{3}$ ). Iron-depleted medium was obtained by treating standard citrate medium with 8-hydroxyquinoline (see Methods).

$\begin{array}{lcc}\text { Growth medium } & \begin{array}{c}\text { Growth } \\ (\text { mg dry wt } \\ \left.\text { bacteria } ~^{-1}\right)\end{array} & \begin{array}{c}\text { Pigment } \\ \left(\mathrm{mg} \mathrm{l}^{-1}\right)\end{array} \\ \text { Standard citrate medium } & 844 & \text { traces } \\ \text { Citrate medium + } \mathrm{Fe}^{3+} & 850 & 0 \\ \text { Iron-depleted citrate medium } & 523 & 160\end{array}$

all conditions where this cation was growth-limiting (Fig. $1 b$ ). Extrapolation to zero of the experimentally determined iron-limited growth yields indicated that the standard succinate medium without added iron contained $135 \mu \mathrm{g} \mathrm{Fe} 1^{-1}$, in reasonable agreement with a value of $160 \mu \mathrm{g} \mathrm{l}^{-1}$ calculated from the manufacturers' analytical data for the chemicals used in the medium.

As the standard succinate medium without added iron permitted the synthesis of greater amounts of fluorescent pigment (Fig. 1a) than did the more severely iron-depleted media B and $\mathrm{Q}$, this standard medium was subsequently used to grow cultures for the isolation and purification of the pigment.

Some authors (Gouda \& Chodat, 1963) have attributed an important role in pyoverdine synthesis to the nature of the organic carbon and energy source; depending on their presumed influence on pigment synthesis, such substrates have been classified as either 'chromogenic' or 'anti-chromogenic'. We observed that when succinic acid was replaced by citric acid (or malic acid) at the same concentration $\left(4 \mathrm{~g} \mathrm{l}^{-1}\right)$ in the standard medium, growth of $P$. fluorescens was not accompanied by pigment production. Addition of $1 \mathrm{mg} \mathrm{Fe}^{3+} 1^{-1} \mathrm{did}$ not increase the growth yield. Thus the citrate medium, unlike the standard succinate medium, was not iron-deficient. When the standard citrate medium was pretreated with 8-hydroxyquinoline to reduce its iron content, the growth yield of $P$. fluorescens was diminished and considerable amounts of fluorescent pigment were produced (Table 1). An 'antichromogenic' substrate can thus be converted into a 'chromogenic' one by a specific reduction of the iron content of the medium.

Nevertheless, the specific iron requirements of $P$. fluorescens may vary as a function of the organic carbon and energy source. To investigate this, we determined the quantity of iron incorporated by bacteria growing with succinate and citrate as carbon sources, both in the presence of excess iron. The standard culture media were supplemented prior to inoculation with $200 \mu \mathrm{g} \mathrm{Fe}{ }^{3+} 1^{-1}$ plus ${ }^{59} \mathrm{Fe}$ citrate at $0.4 \mu \mathrm{g}^{59} \mathrm{Fe}^{3+} 1^{-1}$. The cultures were harvested after $40 \mathrm{~h}$ and the cells were washed three times with the corresponding media without added iron. Measurements of radioactivity in the cell pellets showed that succinategrown cells had incorporated $228 \mu \mathrm{g}$ Fe $\left(\mathrm{g}\right.$ dry wt) ${ }^{-1}$, and citrate-grown cells only 140 . As a result of the lesser iron requirement of $P$. fluorescens when growing at the expense of citrate, pigment excretion (the visible manifestation of iron deficiency) occurs only when the absolute iron level in a citrate medium is substantially lower than that in a succinate medium.

\section{Preliminary observations on the properties of the Fe(III)-pigment complex}

Addition of an aqueous solution of $\mathrm{FeCl}_{3}\left(200 \mathrm{mg} \mathrm{Fe}^{3+} \mathrm{1}^{-1}\right)$ to the pigment-containing supernatant from a culture of $P$. fluorescens caused an immediate colour change to brownred accompanied by a total disappearance of fluorescence. These changes, characteristic of the complexation of pyoverdine $\mathrm{P}_{\mathrm{Pt}}$ by $\mathrm{Fe}^{3+}$ were not observed with other cations tested $\left(\mathrm{Al}^{3+}, \mathrm{Cr}^{\mathrm{j}}, \mathrm{Fe}^{2+}, \mathrm{Co}^{2+}, \mathrm{Ni}^{2+}, \mathrm{Pb}^{2+}\right)$. Free pigment, characterized by its yellow-green colour 
and strong fluorescence, could be recovered from the $\mathrm{Fe}(\mathrm{III})$-pigment complex by any of the following treatments: (i) Reduction with sodium dithionite: this liberates $\mathrm{Fe}^{2+}$, which was identified as the ferricyanide complex (Charlot, 1961). (ii) Acidification to $\mathrm{pH} 1$ : this liberates $\mathrm{Fe}^{3+}$ which was identified as the sulphocyanide complex (Charlot, 1961). (iii) Treatment with other strong chelators of $\mathrm{Fe}^{3+}$ : 8-hydroxyquinoline, EDTA, citric acid.

\section{The Fe(III)-pigment complex and its decomposition products}

Chromatography on CM-Sephadex of the Fe(III)-pigment complex prepared from relatively young ( 24 to $40 \mathrm{~h}$ ) cultures revealed two peaks, A and B. The minor peak (A), which eluted first, was heterogeneous, as revealed by electrophoresis at two $\mathrm{pH}$ values (see Methods). It contained a mixture, in roughly equal quantities, of two pigments a and $b$. Electrophoretic analysis of the major peak (B) showed that it consisted of a single component $c$, accompanied by only traces of components $a$ and $b$.

Attempts to purify further the pigment eluted in peak B, whether by repeated chromatography on CM-Sephadex, or by repeated electrophoresis and subsequent elution of the resulting spots, were not successful: electrophoretic analysis showed that peak $\mathbf{B}$, although consisting largely of component $\mathrm{c}$, was always contaminated by traces of components a and b. The two latter components accounted at most for $1 \%$ of the total absorbance. These results suggested that the material of peak $B$, which is the major pigment in the supernatant from young cultures, is slightly unstable in aqueous solution.

Analogous chromatographic analyses were conducted on the Fe(III)-pigment complex isolated from older (70 to $120 \mathrm{~h}$ ) cultures. The amount of pigment associated with peak B diminished progressively with time and was replaced by the heterogeneous pigment fraction associated with peak $\mathrm{A}$. The $\mathrm{pH}$ of the standard succinate medium, initially at $\mathrm{pH} 7$, rose after $40 \mathrm{~h}$ to approximately $\mathrm{pH} 9$, as a result of the utilization of the organic anion by the bacteria. Since the evidence previously described suggested that pyoverdine was slightly unstable in aqueous solution, the extensive decomposition observed in alkaline culture media could reflect a chemical, rather than a biological degradation. Therefore solutions of purified pyoverdine and of its $\mathrm{Fe}$ (III) complex were prepared in water adjusted to $\mathrm{pH} 5$, 7 and 9 , by adding either acetic acid or $\mathrm{Na}_{2} \mathrm{CO}_{3}$, and agitated at $25^{\circ} \mathrm{C}$ for $70 \mathrm{~h}$. After complexing the free pyoverdine with $\mathrm{Fe}^{3+}$, each fraction was subjected to chromatography on CM-Sephadex, followed by electrophoresis. The residual desferri pigment decreased from $94 \%$ (at pH 5) to $60 \%$ (at pH 9) whereas the Fe(III)-pigment complex itself decreased from $97 \%$ to $86 \%$ at these $\mathrm{pH}$ values. Pyoverdine and, to a lesser degree, the complex were evidently alkali-labile. Furthermore, the degradation both of the free pigment and of the $\mathrm{Fe}(\mathrm{III})$ complex under mild alkaline conditions yielded a mixture of pigments indistinguishable in their chromatographic and electrophoretic behaviour from those of fraction $A$, as initially characterized in the supernatant of culture media.

To summarize, the available evidence strongly suggests that $P$. fluorescens synthesizes only one molecular species of the pyoverdine type. However, the native pigment is labile in aqueous solution, particularly under mildly alkaline conditions, and gives rise to several pigmented decomposition products. Therefore to minimize the chemical decomposition of pyoverdine, cultures were maintained throughout growth at a $\mathrm{pH}$ value below 7.3 and were harvested shortly after entry into the stationary phase.

\section{Physicochemical properties of the pigment and its $\mathrm{Fe}(\mathrm{III})$ complex}

The molecular weight of the free pigment was determined by tonometry as $1500 \pm 75$. The absorption spectrum in water of the free pigment showed two main bands: one at $230 \mathrm{~nm}$ $(\epsilon=32000)$ with a shoulder at $255 \mathrm{~nm}$, the other at $385 \mathrm{~nm}(\epsilon=16500)$ with shoulders at 365 and $400 \mathrm{~nm}$ (Fig. 2). As shown in Fig. 3, at pH values $\leqslant 5$, there were two peaks with maxima at 365 and $380 \mathrm{~nm}$ in the visible region; at $\mathrm{pH}$ values $\geqslant 7$, there was only one peak 


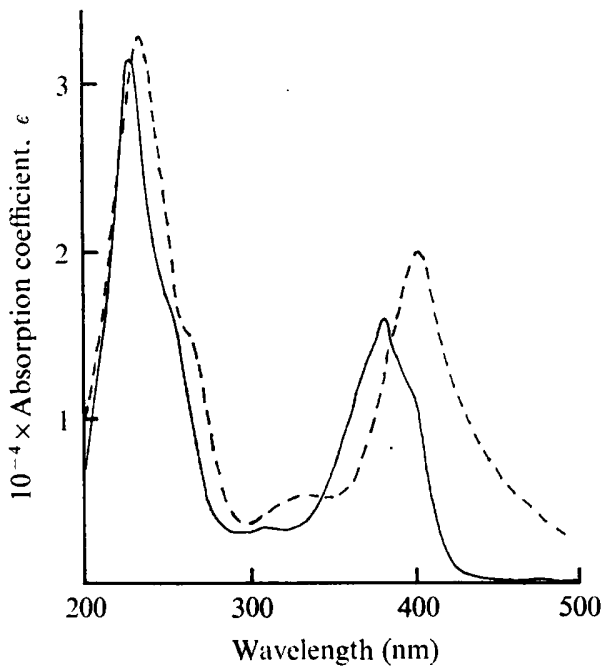

Fig. 2

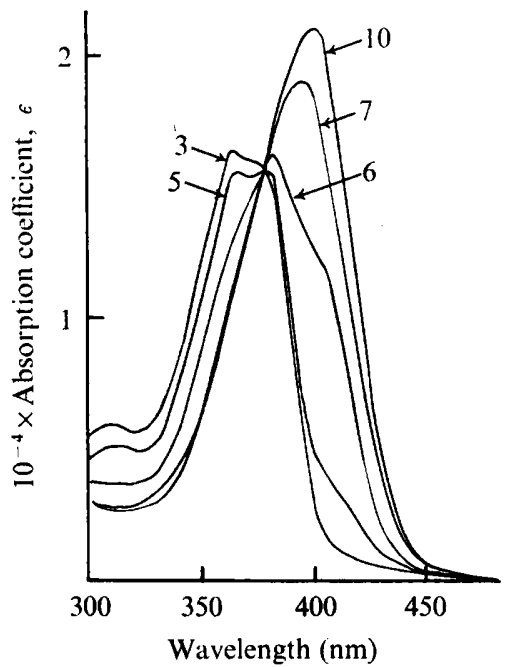

Fig. 3

Fig. 2. Absorption spectra of pyoverdine $\mathrm{P}_{\mathrm{Pt}}(-)$ and its $\mathrm{Fe}(\mathrm{III})$ complex (---) in aqueous solution. Fig. 3. Visible absorption spectrum of pyoverdine $\mathrm{Pf}_{\mathrm{Pf}}$ as a function of $\mathrm{pH}$. $\mathrm{pH}$ values are indicated beside the spectra.

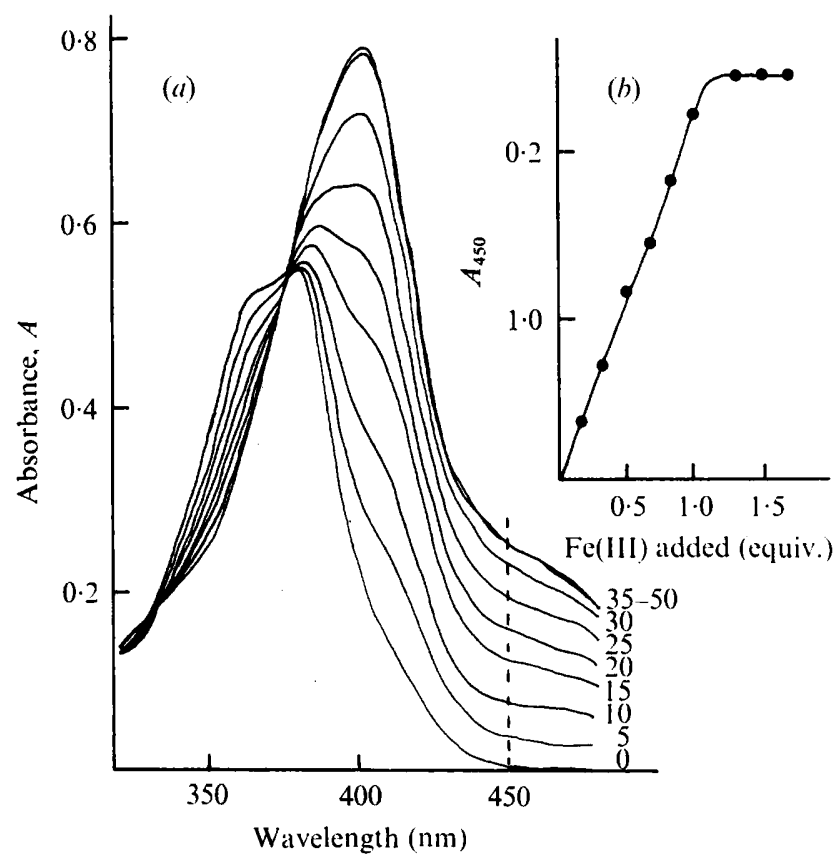

Fig. 4. Determination of the stoicheiometry of the Fe(III)-pyoverdine ${ }_{\mathrm{Pf}}$ complex. (a) Change in the absorption spectrum of pyoverdine $\mathrm{Pf}_{\mathrm{Pf}}$ as a function of the amount of $\mathrm{Fe}(\mathrm{III})$ added. The numbers beside the spectra indicate the volumes $(\mu \mathrm{l})$ of $3.25 \mathrm{mM}-\mathrm{FeCl}_{3}$ solution added (see Methods). (b) Increase in absorption at $450 \mathrm{~nm}$ (derived from Fig. $4 a$ ) as a function of the equivalent amounts of added $\mathrm{Fe}$ (III). 
in this region, which shifted from $402 \mathrm{~nm}(\mathrm{pH} 7)$ to $410 \mathrm{~nm}(\mathrm{pH} \mathrm{10)}$. The spectrum in the ultraviolet region was essentially invariant as a function of $\mathrm{pH}$.

The absorption spectrum of the Fe(III)-pigment complex (Fig. 2) had maxima at $235 \mathrm{~nm}$ $(\epsilon=33000)$ and at $403 \mathrm{~nm}(\epsilon=20000)$ with a pronounced shoulder at $450 \mathrm{~nm}(\epsilon=6800)$. It was pH-invariant.

The large difference in absorbance at $450 \mathrm{~nm}$ between the Fe(III)-pigment complex $(\epsilon=$ $6800)$ and the free pigment $(\epsilon=0)$ made it possible to determine spectrophotometrically the concentration of the $\mathrm{Fe}$ (III)-pigment complex present in a mixture of both species. As shown in Fig. 4, the stoicheiometry of the complex is $1: 1$.

The uncorrected fluorescence spectrum of pyoverdine $\mathrm{P}_{\mathrm{Pf}}$, measured at $\mathrm{pH} 7 \cdot 0(0 \cdot 1 \mathrm{M}-$ phosphate buffer), had a maximum of excitation at $398 \mathrm{~nm}$, and of emission at $470 \mathrm{~nm}$. At lower $\mathrm{pH}(1 \%$ acetic acid), the maxima were shifted to $384 \mathrm{~nm}$ and $510 \mathrm{~nm}$, respectively. The Fe(III)-complex was non-fluorescent.

\section{Stability constant of the Fe(III)-pigment complex}

The stability constant $K_{2}$ of the complex was measured as described by Rosotti \& Rosotti (1961) using EDTA as a competitive chelator of $\mathrm{Fe}^{3+}$. In the presence of EDTA, the Fe(III)pyoverdine $_{\mathrm{Pf}}$ complex (PFe) was partly decomplexed:

$$
\mathrm{PFe}+\mathrm{EDTA} \rightleftharpoons \mathrm{P}+\mathrm{EDTA}-\mathrm{Fe}
$$

the equilibrium constant $K_{1}$ being

$$
\frac{[\mathrm{PFe}][\mathrm{EDTA}]}{[\mathrm{P}][\mathrm{EDTA}-\mathrm{Fe}]}
$$

Equation (1) represents two equilibria:

$$
\mathrm{PFe} \rightleftharpoons \mathrm{P}+\mathrm{Fe}
$$

and

$$
\mathrm{EDTA}+\mathrm{Fe} \rightleftharpoons \mathrm{EDTA}-\mathrm{Fe}
$$

with equilibrium constants:

$$
K_{2}=\frac{[\mathrm{PFe}]}{[\mathrm{P}][\mathrm{Fe}]} \quad \text { and } \quad K_{3}=\frac{[\mathrm{EDTA}-\mathrm{Fe}]}{[\mathrm{EDTA}][\mathrm{Fe}]}
$$

The stability constant of PFe is thus:

$$
K_{2}=K_{1} \times K_{3}
$$

The value of $K_{3}$ as a function of $\mathrm{pH}$ is known (Anderegg et al., 1963). If we neglect the concentration of free iron, then $[\mathrm{P}]=[\mathrm{EDTA}-\mathrm{Fe}]$. Since $[\mathrm{P}]=[\mathrm{PFe}]_{\text {intial }}-[\mathrm{PFe}]$ and $[$ EDTA $]=[\text { EDTA }]_{\text {initial }}-[$ EDTA-Fe $], K_{1}$ could be calculated by determination of the values at equilibrium of $[\mathrm{PFe}]$. These are directly proportional to the absorbance at $450 \mathrm{~nm}$, since none of the other reacting species absorbs significantly at this wavelength.

In the experiment illustrated in Fig. 5, where all solutions were buffered at $\mathrm{pH} 7.0$ with $0 \cdot 1 \mathrm{M}$-phosphate, a range from $0 \cdot 125$ to $15 \mathrm{mm-EDTA}$ was necessary to achieve satisfactory decomplexation of the pigment. The mean value of the stability constant, $K_{\mathrm{PFe} \text {, pH7 }}$, was found to be equal to $189 \times K_{\mathrm{EDTA}, \mathrm{pH} 7}$. Since the stability constant of EDTA at pH 7.0 is $10^{22}$ (Anderegg et al., 1963), a value for $K_{2}$ of $1.9 \times 10^{24}$ could be deduced at pH 7.0.

$K_{2}$ was a function of $\mathrm{pH}$, and determinations of the apparent stability constants at a series of $\mathrm{pH}$ values (Table 2) permitted a calculation by extrapolation to alkaline $\mathrm{pH}$ values of the real stability constant which was of the order of $10^{32}$ (Fig. 6), characteristic of a highly stable $\mathrm{Fe}^{3+}$ complex (Anderegg et al., 1963). 


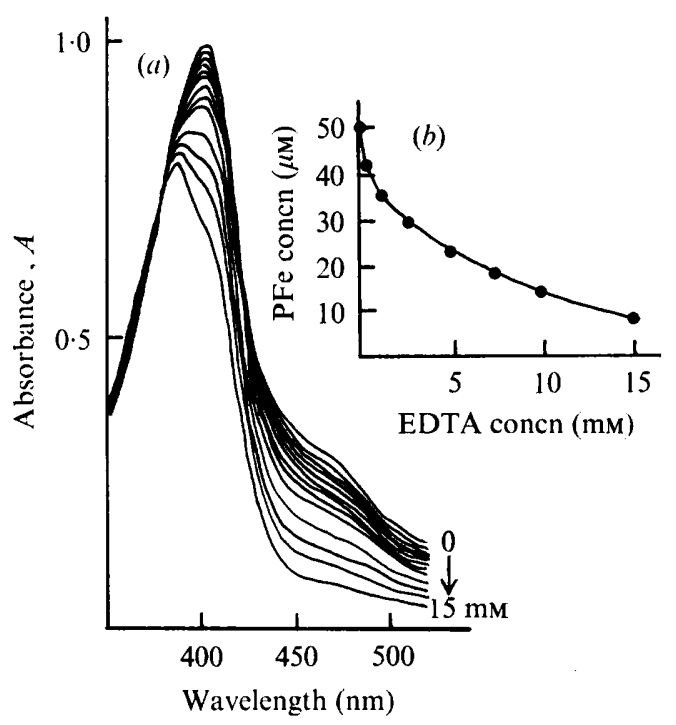

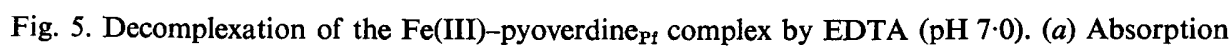

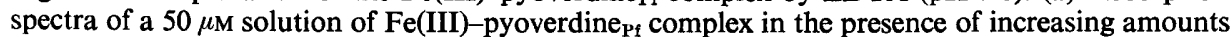
( 0 to $15 \mathrm{~mm}$ ) of EDTA, prepared as described in Methods. (b) Decrease in the concentration of the $\mathrm{Fe}$ (III)-pyoverdine $\mathrm{Pf}_{\mathrm{P}}$ complex (measured by absorption at $450 \mathrm{~nm}$ ) as a function of added EDTA.

Table 2. Variation of the apparent stability constant $\left(K_{2}\right)$ of the iron $(I I I)$-pyoverdine ${ }_{\mathrm{Pf}}$ complex as a function of $\mathrm{pH}$

For definitions of $K_{1}, K_{2}$ and $K_{3}$, see text.

$\begin{array}{rcccc}\text { pH } & K_{1} & K_{3} & K_{2} & \log K_{2} \\ 5 & 0 \cdot 27 & 10^{18} & 0 \cdot 27 \times 10^{18} & 17 \cdot 44 \\ 6 & 3 & 10^{20} & 3 \cdot 00 \times 10^{20} & 20 \cdot 47 \\ 7 & 189 & 10^{22} & 1 \cdot 89 \times 10^{24} & 24 \cdot 26 \\ 8 & 5000 & 10^{23} & 5 \cdot 00 \times 10^{26} & 26 \cdot 70 \\ 10 & 10600 & 10^{27} & 1 \cdot 06 \times 10^{31} & 31 \cdot 02\end{array}$

\section{DISCUSSION}

Many investigators have shown that the synthesis of pyoverdines in fluorescent pseudomonads is inhibited by adding $\mathrm{Fe}^{3+}$ to cultures (King et al., 1948; Koepsell, 1950; Totter \& Moseley, 1953; Lenhoff, 1963; Love \& Hulcher, 1964; Palumbo, 1972). Nevertheless, the specific role of iron as a regulator of fluorescent pigment synthesis has remained unclear, since the synthesis appeared also to be regulated by other factors, notably the nature of the organic substrate (Gouda \& Greppin, 1965; Gouda \& Chodat, 1963).

The experiments described here reveal that the concentration of $\mathrm{Fe}^{3+}$ is the sole factor that regulates pyoverdine synthesis by $P$. fluorescens. The observation that no fluorescent pigment was produced when citric acid or malic acid was used as the substrate was due to these cells not being iron-limited. Succinate-grown cells had a specific iron requirement of about 1.6 times that of citrate-grown cells and thus readily became iron-deficient. The classification of organic substrates for fluorescent pseudomonads into the categories of 'chromogens' and 'anti-chromogens' is, accordingly, unjustified. Our observations suggest that any organic substrate can support pyoverdine synthesis but also show that the absolute level of $\mathrm{Fe}^{3+}$ at which growth becomes limited may vary significantly with the nature of the substrate.

The specific derepression of pyoverdine synthesis that results from iron limitation suggested that the pigment might play a role in either the transport or the metabolism of iron. This 


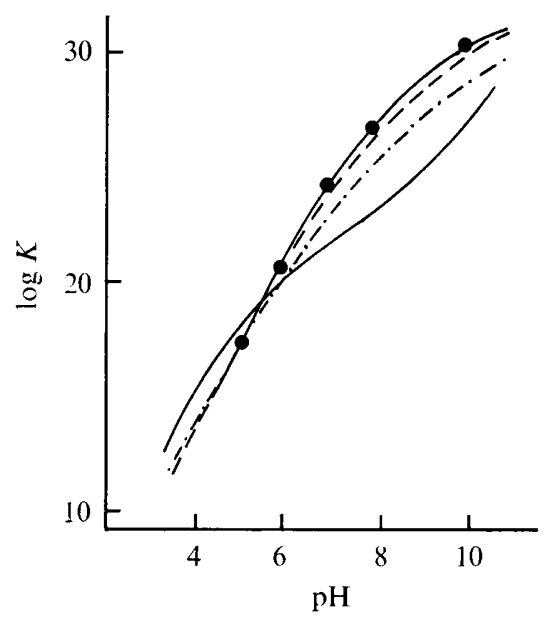

Fig. 6. Apparent stability constants of the Fe(III)-pyoverdine ${ }_{\mathrm{Pl}}$ complex as a function of $\mathrm{pH}(\boldsymbol{O})$, compared with reported values (Anderegg et al., 1963) for other siderophores: ferroxamine B (---); ferrichrome (---・-); EDTA-Fe(III) complex (-).

hypothesis was strengthened by the discovery that the fluorescent pigment is a powerful chelator of $\mathrm{Fe}^{3+}$, with an affinity constant for this cation of about $10^{32}$. Formation of the $\mathrm{Fe}(\mathrm{III})$-pigment complex permitted the purification of the fluorescent pigment by a method analogous to that used by Zähner et al. (1963) for the purification of the microbial iron chelators known as desferrisiderochromes (Keller-Schierlein et al., 1964).

Pyoverdine was shown to be chemically unstable under mild alkaline conditions. The mixture of pigments reported by several workers (Chodat \& Gouda, 1961 ; Favre \& Greppin, 1971; Michea \& Greppin, 1974) is probably an artefact caused by the lability of the native pigment at $\mathrm{pH}$ values above $7 \cdot 0$.

The properties of pyoverdine $\mathrm{P}_{\mathrm{P}}$ are consistent with its role as a siderophore (Neilands, 1973). They include specific derepression under conditions of $\mathrm{Fe}^{3+}$ deficiency, and a very high affinity for $\mathrm{Fe}^{3+}$, together with a lack of affinity for $\mathrm{Fe}^{2+}$. Moreover, the apparent stability constants of the Fe(III)-pigment complex are comparable to those of two other siderophores (Fig. 6). The role of pyoverdine in facilitating the transport of $\mathrm{Fe}^{3+}$ into the cell of $P$. fluorescens is described in the following paper (Meyer \& Hornsperger, 1978).

We wish to thank Professor R. Y. Stanier for invaluable advice and discussion, and Professor B. Wurtz in whose laboratory this work was performed. We also gratefully acknowledge the interest shown by Dr J. F. Biellmann in this work.

\section{REFERENCES}

ANDERegG, G., L'Eplattenier, F. \& SchwarzenBACH, G. (1963). Hydroxamatkomplexe: III. Eisen(III)-Austausch zwischen Sideraminen und Komplexonen. Diskussion der Bildungskonstanten der Hydroxamatkomplexe. Helvetica chimica acta 46, 1409-1422.

BAGHDIANTZ, A. (1952). Role of zinc in appearance of component II of the pigment of Pseudomonas fluorescens (Flügge-Migula). Archives des sciences, Genève 5, 47-48.

Birkhoffer, L. \& Birkhoffer, A. (1948). Riboflavine, a component of 'bacterial fluorescein'. Zeitschrift für Naturforschung 3b, 136.

Blanchetière, A. (1920). Action du Bacillus fluorescent liquefiant de Flügge sur l'asparagine en milieu chimiquement défini. Annales de l'Institut Pasteur 34, 392-411.

Chakrabarty, A. M. \& Roy, S. C. (1964a). Effect of trace elements on the production of pigments by a pseudomonad. Biochemical Journal 93, 228-231.

Chakrabarty, A. M. \& Roy, S. C. $(1964 b)$. Characterization of a pigment from a pseudomonad. Biochemical Journal 93, 144-148.

Charlot, G. (1961). Analyse Qualitative Rapide des Cations et des Anions. Paris: Dunod.

Chodat, F. \& Gouda, S. (1961). Contribution à l'étude du pigment de Pseudomonas fluorescens Migula. Pathologia et microbiologia 24, 840-847. 
Elliot, R. P. (1958). Some properties of Pyoverdine, the water-soluble pigment of the pseudomonads. Applied Microbiology 6, 241-246.

Favre, J. \& GreppIN, H. (1971). Séparation de l'extrait pigmentaire de Pseudomonas fluorescens sur gel de Sephadex G25. Saussurea 2, 25-28.

Georgia, F. R. \& Poe, C. F. (1931). Study of bacterial fluorescence in various media. I. Inorganic substances necessary for bacterial fluorescence. Journal of Bacteriology 22, 349-361.

Giral, F. (1936). Sobre los liocromos característicos del grupo de bacterias fluorescentes. Anales de la Sociedad española de física y química 34, 667-693.

Gouda, S. \& Chodat, F. (1963). Glyoxylate et succinate, facteurs déterminant respectivement l'hypochromie et l'hyperchromie des cultures de Pseudomonas fluorescens. Pathologia et microbiologia 26, 655-664.

GoudA, S. \& Greprin, H. (1965). Biosynthèse pigmentaire chez Pseudomonas fluorescens en fonction de la concentration du substrat hydrocarboné ou aminé. Archives des sciences, Genève 18, 716-721.

Greppin, H. \& GoudA, S. (1965). Action de la lumière sur le pigment de Pseudomonas fluorescens Migula. Archives des sciences, Genève 18, 721-725.

HuLCHER, F. H. (1968). Activation of 6-phosphogluconate dehydrase by Pyoverdine. Biochemical and Biophysical Research Communications 31, 247251.

Keller-Schierlein, W., Prelog, V. \& Zähner, H. (1964). Siderochrome. (Natürliche Eisen(III)trihydroxamat-Komplexe). Fortschritte der Chemie organischer Naturstoffe 22, 279-322.

King, J. V., Campbell, J. J. R. \& Eagles, B. A. (1948). Mineral requirements for fluorescin production by Pseudomonas. Canadian Journal of Research 26 C, 514-519.

Koepsell, J. (1950). Gluconate oxidation by Pseudomonas fluorescens. Journal of Biological Chemistry 186, 743-751.

LENHOFF, H. M. (1963). An inverse relationship of the effects of oxygen and iron on the production of fluorescin and cytochrome $c$ by Pseudomonas fluorescens. Nature, London 199, 601-602.

LEPIERRE, C. (1895). Recherches sur la fraction fluorescinogène des microbes. Annales de l'Institut Pasteur 8, 643-663.

Lluch, C., Callao, V. \& Olivares, J. (1973). Pigment production by Pseudomonas reptilivora. I. Effect of iron concentration in culture media. Archiv für Mikrobiologie 93, 239-243.

Love, S. H. \& Hulcher, F. H. (1964). Green fluorescent pigment accumulated by a mutant of Cellvibrio gilvus. Journal of Bacteriology 87, 39-45.

Meyer, J. M. \& HoRnSPERGER, J. M. (1978). Role of pyoverdine $_{\mathbf{P f}}$, the iron-binding fluorescent pigment of Pseudomonas fluorescens, in iron transport. Journal of General Microbiology 107, 329-331.

Michea, M. \& Greppin, H. (1974). Separation et évolution du complexe pigmentaire de Pseudomonas fluorescens Migula. Comptes rendus de la Société d'histoire naturelle de Genève 8, 19-31.

NeILANDS, J. B. (1973). Microbial iron transport compounds (siderochromes). In Inorganic Biochemistry, vol. I, pp. 167-209. Edited by G. L. Eichhorn. Amsterdam: Elsevier.

Palleroni, N. J. \& DoudorofF, M. (1974). The genus Pseudomonas. In Bergey's Manual of Determinative Bacteriology, 8th edn, pp. 217-243. Edited by R. E. Buchanan \& N.E. Gibbons. Baltimore: Williams \& Wilkins.

Palleroni, N. J., Kunisawa, R., Contopoulou, R. \& DoudorofF, M. (1973). Nucleic acid homologies in the genus Pseudomonas. International Journal of Systematic Bacteriology 23, 333-339.

Palumbo, S. A. (1972). Role of iron and sulfur in pigment and slime formation by Pseudomonas aeruginosa. Journal of Bacteriology 111, 430-436.

RosotTi, J. C. \& RosotTI, H. (1961). The Determination of Stability Constants. New York: McGraw Hill.

Stanier, R. Y., Palleroni, N. J. \& Doudoroff, M. (1966). The aerobic pseudomonads: a taxonomic study. Journal of General Microbiology 43, 159271.

Sullivan, M. X. (1905). Synthetic culture media and the biochemistry of bacterial pigments. Journal of Medical Research 14, 109-160.

Theodore, J. S. \& Schade, A. L. (1965). Growth of Staphylococcus aureus in media of restricted and unrestricted inorganic iron availability. Journal of General Microbiology 39, 75-83.

TOTTER, J. R. \& MOSELEY, F. T. (1953). Influence of the concentration of iron on the production of Fluorescin by Pseudomonas aeruginosa. Journal of Bacteriology 65, 45-47.

TURFreIJER, A. (1942). Pyoverdinen de groene fluorescende Kleurstoffen van Pseudomonas fluorescens. Thesis, University of Amsterdam. British Abstracts 16, 16578.

WARING, W. S. \& Werkman, C. H. (1942). Growth of bacteria in an iron-free medium. Archives of Biochemistry 1, 303-310.

Wurtz, B. (1954). Antagonisme entre les bacteries lactiques et protéolytiques des ensilages. Conférence Européenne des Herbages, Paris, 288-297.

ZÄHNER, H., Keller-Schierlein, W., Hutter, R., Hess-Leisinger, K. \& DeER, A. (1963). Sideramine aus Aspergillaceen. Archiv für Mikrobiologie 45, 119-135. 